\title{
PENGARUH KOMUNIKASI PEMASARAN DAN KERELASIAN NASABAH TERHADAP LOYALITAS NASABAH BANK NAGARI CABANG UTAMA PADANG
}

\author{
Fisky Noverta, Desfriana Sari \\ Sekolah Tinggi Ilmu Ekonomi KBP \\ fiskyverta11@gmail.com
}

\begin{abstract}
ABSTRCT
This study aims to determine the factors of customer loyalty, the population used in this study is customers who come to Bank Nagari, the Main Branch of the City of Padang. The sample of this study is 100 respondents and the technique used is the Slovin formula which has fulfilled the requirements that are feasible to be used as samples. Data analysis techniques used multiple linear regression analysis. The results of the study show that the variable (Y) Marketing Communication (X1), Customer Relationship variable (X2) simultaneously (together) affects the Customer Loyalty of the Main Branch of Bank Nagari in Padang and the indicators in this study are valid. Based on the results of the study obtained a figure of $19.1 \%$ that affects Customer Loyalty to Bank Nagari Padang Main Branch can be explained by tourist attraction objects, location and facilities. While the remaining $80.9 \%$ is influenced by other factors not tested in this study.

Keywords: Customer Loyalty, Marketing Communication and Customer Relationship
\end{abstract}

\section{PENDAHULUAN}

Sejalan pesatnya peningkatan ekonomi dan bisnis di dunia pada umumnya, kegiatan bisnis bank umum semakin canggih dan beraneka ragam. Perubahan ekonomi dan berbagai usaha pemerintah untuk mengendalikan perekonomian ada merugikan dan kadang-kadang menguntungkan. Keadaan tersebut juga berpengaruh terhadap dunia perbankan di Indonesia, sehingga dalam menjalankan usaha perbankan selalu berasaskan demokrasi ekonomi dengan menggunakan prinsip kehati-hatian dan selektif dalam menyalurkan kreditnya. Perkembangan perekonomian nasional maupun internasional yang senantiasa bergerak cepat disertai tantangan yang semakin luas,perlu ketanggapan perbankan nasional dalam menjalankan fungsi dan tanggung jawabnya.

Sejalan dengan fungsi bank sebagai badan usaha yang menjalankan peran intermediasi, penyaluran kredit merupakan salah satu kegiatan usaha bank yang dominan. Oleh karena itu, tidak heran apabila pendapatan bunga kredit menjadi sumber pendapatan terbesar perbankan. Kredit sebagai kegiatan usaha yang utama perbankan senantiasa mengandung risiko yang relatif besar. Timbulnya kredit atau kredit bermasalah dan kerugian karena pemberian kredit sebagai risiko kredit, memengaruhi tingkat kesehatan bank dan berkurangnya pendapatan bunga kredit yang seharusnya diterima.

Sejalan kegiatan bisnis, komunikasi pemasaran menjadi sangat penting, dan merupakan bagian dari bauran pemasaran. Karena itu untuk mempertahankan pelanggan dan menarik pelanggan yang baru, perusahaan biasanya melakukan komunikasi pemasaran yang sesuai dengan karakter pelanggan sasarannya. (Rusman, 2015) menyatakan bahwa komunikasi pemasaran akan menentukan dampak yang merupakan kinerja bisnis meliputi loyalitas pelanggan, sehingga berdampak pada loyalitas pelanggan. Demikian juga Fill (1995) dalam 
(Nashihuddin, 2016) menyatakan kegiatan promosi akan mendorong konsumen untuk melakukan pembelian ulang.

Menurut Clow dan Baack (2007) dalam (Rusman, 2015) , komunikasi pemasaran terintegrasi mengkoordinasikan dan mengintegrasikan semua elemen dari komunikasi pemasaran untuk memaksimalkan komunikasi pada konsumen dengan biaya yang relatif rendah.Komunikasi pemasaran terintegrasi merupakan integrasi dari komponennya yang mencakup 8 hal, yaitu misi, target pasar, uang, media, pesan, bauran, pengukuran, dan pemasaran terhubung. Bauran merupakan gabungan dari alat promosi (yang di dalamnya ada iklan, penjualan pribadi, promosi penjualan, relasi publik, dan penjualan langsung).

\section{Keterkaitan Komunikasi Pemasaran dan Loyalitas Nasabah}

Menurut Clow dan Baack (2007) dalam (Aqeela, 2015), komunikasi pemasaran terintegrasi mengkoordinasikan dan mengintegrasikan semua elemen dari komunikasi pemasaran untuk memaksimalkan komunikasi pada konsumen dengan biaya yang relatif rendah. Komunikasi pemasaran terintegrasi merupakan integrasi dari komponennya, yang mencakup 8 hal, yaitu misi, target pasar, uang, media, pesan, bauran, pengukuran, dan pemasaran terhubung.

Penelitian yang dilakukan oleh Ningtyas dan Rachmad (2011) dalam (Rusman, 2015) yang berjudul "Pengaruh Kepercayaan, Komitmen, Komunikasi, Penanganan Masalah dan Kepuasan Nasabah Terhadap Loyalitas Nasabah Bank Muamalat di Surabaya“.

Instrumen pengukuran yang digunakan adalah non probabylity sampling dengan teknik judgment sampling, yaitu responden harus memenuhi syarat yang diajukan oleh peneliti dan juga menggunakan kuesioner yang dibagikan pada nasabah Bank Muamalat Surabaya. Penelitian ini menggunakan analisis statistik regresi berganda dengan menggunakan spss 16.0. Analisis ini dilakukan untuk menguji pangaruh variabel bebas (independent) terhadap variabel terikat (dependent).

Berdasarkan argumentasi diatas, hipotesis pertama dan kedua yang dapat dibangun adalah sebagai berikut :

H1: Komunikasi Pemasaran berpengaruh positif dan signifikan terhadap Loyalitas Nasabah

\section{Keterkaitan Kerelasian Nasabah dan Loyalitas Nasabah}

Dalam upaya pemeliharaan kepercayaan nasabah di Bank Nagari Cabang Utama Padang melakukan upaya untuk meningkatkan loyalitas nasabah mengingat target jumlah nasabah yang terus meningkat dari tahun ke tahun. Namun demikian target tersebut masih belum dapat diimbangi dengan upaya peningkatan komunikasi pemasaran dan kerelasian nasabah yang dapat mempegaruhi respon nasabah dan selanjutnya berpengaruh terhadap loyalitas nasabah.

Penelitian yang dilakukan oleh Amin dan Sulaksono (2015) dalam (Rusman, 2015) yang berjudul "Pengaruh Komunikasi Pemasaran dan Kerelasian Nasabah terhadap Loyalitas Nasabah pada Bank Rakyat Indonesia Jember". Hasil pengujian koefisien jalur menunjukkan bahwa kerelasian nasabah tidak berpengaruh secara signifikan terhadap loyalitas nasabah. Karena nilai t hitung lebih kecil dari pada t-tabel. Berdasarkan hasil pengujian tersebut maka dapat disimpulkan bahwa kerelasian nasabah berpengaruh secara signifikan terhadap loyalitas nasabah adalah terbukti (ditolak). 
Berdasarkan argumentasi diatas, hipotesis pertama dan kedua yang dapat dibangun adalah sebagai berikut :

H2: Kerelasian Nasabah berpengaruh positif dan signifikan terhadap Loyalitas Nasabah

\section{METODE PENELITIAN}

Dalam penelitian ini penulis menggunakan pendekatan kualitatif. Menurut Sugiyono (2009:15) dalam (Aqeela, 2015) penelitian kualitatif adalah suatu metode penelitian yang berlandasan pada filsafat postpositifme, digunakan untuk meneliti pada kondisi objek yang alamiah dimana peneliti adalah instrument kunci, pengambilan sampel sumber data dilakukan secara purposive, teknik pengumpulan dengan triangulasi. Analisis data bersifat induktif / kualitatif dan hasil penelitian kualitatif lebih menekankan makna daripada generalisasi.

Menurut Ferdinand (2006) dalam (Willem et al., 2014), sampel adalah sebagian dari jumlah populasi yang dapat mewakili berjalannya suatu penelitian yang memiliki karakteristik sesuai dengan penelitian akan dilakukan. Penelitian ini, hanya sebagian anggota populasi yang diambil untuk dijadikan sampel, namun kesimpulannya dapat digeneralisasikan untuk seluruh populasi. Jadi besarnya sampel penelitian yang digunakan dalam penelitian ini adalah berjumlah 100 orang nasabah.

\section{Definisi Operasional Variabel Penelitian}

\section{Tabel 1}

\section{Definisi Variabel}

\begin{tabular}{|c|c|c|c|}
\hline Variabel & Definisi & Indikator & Sumber \\
\hline $\begin{array}{c}\text { Komunikasi } \\
\text { Pemasaran (X1) }\end{array}$ & $\begin{array}{c}\text { Suatu proses mendapatkan } \\
\text { apa yang mereka butuhkan } \\
\text { dan inginkan dengan } \\
\text { menciptakan, menawarkan, } \\
\text { dan secara bebas } \\
\text { mempertukarkan produk } \\
\text { yang bernilai dengan pihak } \\
\text { lain. }\end{array}$ & $\begin{array}{c}\text { Membeli Produk } \\
\text { Merekomendasikan } \\
\text { Informasi } \\
\text { Pengunjungan }\end{array}$ & $\begin{array}{c}\text { Kotler dan Keller } \\
(2007: 6)\end{array}$ \\
\hline $\begin{array}{c}\text { Kerelasian } \\
\text { Nasabah } \\
\text { (X2) }\end{array}$ & $\begin{array}{l}\text { Proses mengelola informasi } \\
\text { rinci tentang masing masing } \\
\text { pelanggandansecara cermat } \\
\text { mengelola semua titik } \\
\text { sentuhan pelanggandemi } \\
\text { memaksimalkan kesetiaan } \\
\text { pelanggan. }\end{array}$ & $\begin{array}{c}\text { Mempertahankan } \\
\text { pelanggan } \\
\text { Berorentasi pada manfaat } \\
\text { produk } \\
\text { Menekankan pada } \\
\text { pelayanan } \\
\text { Sering kontak dengan } \\
\text { pelanggan } \\
\end{array}$ & $\begin{array}{l}\text { Keller } \\
(2007)\end{array}$ \\
\hline $\begin{array}{c}\text { Loyalitas } \\
\text { Nasabah } \\
\text { (Y) }\end{array}$ & $\begin{array}{l}\text { Komitmen untuk membela } \\
\text { secara mendalam untuk } \\
\text { membeli kembali atau } \\
\text { berlangganan kembali } \\
\text { produk atau layanan yang } \\
\text { dipilih secara konsisten }\end{array}$ & $\begin{array}{c}\text { Melakukan pembelian } \\
\text { berulang } \\
\text { Membeli antar lini produk } \\
\text { atau jasa } \\
\text { Mereferensikan kepada } \\
\text { orang lain } \\
\text { Siap menghadapi pesaing }\end{array}$ & $\begin{array}{l}\text { Griffin } \\
(2008: 6)\end{array}$ \\
\hline
\end{tabular}

\section{Teknik Analisa Data}

Untuk mempermudah pengukuran masing-masing item pertanyaan maka akan diberi skor atau nilai berdasarkan ukuran interval/rasio. Yaitu skala yang di dasarkan pada rangking, 
diurutkan jadi jenjang yang lebih tinggi sampai jenjang terendah atau sebaliknya (Ridwan, 2007:7).

Skala yang digunakan dalam penelitian ini adalah skala likert. Skala ini digunakan untuk mengukur sikap, pendapat dan persepsi seseorang atau sekelompok tentang kejadian atau gejala sosialnya (Ridwan, 2007:12).

Uji Asumsi Klasik Untuk mendeteksi normalitas data dalam penelitian ini dilakukan dengan uji kolmogorov-smirnov test.Pengujian ini bertujuan untuk mengetahui apakah sampel yang digunakan dalam penelitian ini berdistribusi normal atau tidak.

Uji heterokedastisitas bertujuan menguji apakah dalam model regresi terjadi ketidaksamaan variancedari residual satu pengamatan ke pengamatan yang lain.

Uji multikolinieritas bertujuan untuk menguji apakah model regresi ditemukanadanya korelasi antar variabel bebas (independen). Model rgresi yang baik seharusnya tidak terjadi korelasi diantara variabel bebas (tidak terjadi Multikolinieritas).

Analisis regresi untuk menjawab hipotesis atau rumusan masalah.Analisis regresi pada dasarnya adalah studi mengenai ketergantungan variabel dependen (terikat) dengan satu atau lebih variabel independen (variabel bebas) dengan tujuan untuk mengestimasi dan memprediksi rata-rata populasi atau nilai rata-rata variabel dependen berdasarkan nilai variabel independen yang diketahui. (Suharli, 2004).

\section{HASIL DAN PEMBAHASAN Analisa Deskriptif}

Pada sub bab ini diuraikan tentang deskripsi masing-masing variable penelitian, baik variabel bebas maupun variabel terikat. Distribusi frekuensi dari masing-masing variabel akan disajikan dalam tabel distribusi frekuensi. Pada penelitian ini rata rata TCR sebesar 90\% yang mana sangat baik.

\section{HASIL PENGUJIAN HIPOTESIS}

Uji t bertujuan untuk mengetahui besarnya pengaruh masing-masing variabel independen secara individual (parsial) terhadap variabel dependen (Nugroho, 2005). Hasil uji ini pada output SPSS dapat dilihat pada tabel Coefficients ${ }^{a}$.

\begin{tabular}{|c|c|c|c|c|c|c|}
\hline & & \multicolumn{2}{|c|}{$\begin{array}{l}\text { Unstandardized } \\
\text { Coefficients }\end{array}$} & \multirow{2}{*}{$\begin{array}{c}\begin{array}{c}\text { Standardized } \\
\text { Coefficients }\end{array} \\
\text { Beta }\end{array}$} & \multirow[b]{2}{*}{$\mathrm{t}$} & \multirow[b]{2}{*}{ Sig. } \\
\hline \multicolumn{2}{|c|}{ Model } & $B$ & Std. Error & & & \\
\hline \multirow[t]{3}{*}{1} & (Constant) & 17.825 & 2.408 & & 7.402 & .000 \\
\hline & $\begin{array}{l}\text { komunikasi } \\
\text { pemasaran }\end{array}$ & .204 & .086 & .260 & 2.363 & .020 \\
\hline & kerelasian nasabah & 282 & .122 & .254 & 2.311 & .023 \\
\hline
\end{tabular}

a. Dependent Variable: loyalitas nasabah

Data diolah SPSS

Berdasarkan tabel uji parsial di atas dapat diketahui bahwa varibael komunikasi pemasaran mempunyai pengaruh yang signifikan terhadap loyalitas nasabah karena nilai sebesar 0.020 , berarti signifikansi $<0,05$. Sedangkan variabel kerelasian nasabah juga mempunyai 
pengaruh yang signifikan terhadap loyalitas nasabah karena nilai sebesar 0.020 karena memiliki nilai signifikan $0.023<0,05$.

\section{Pengaruh Komunikasi Pemasaran terhadap Loyalitas Nasabah}

Berdasarkan pada tabel Uji-t yang telah disajikan untuk hipotesis pertama didapatkan hasil estimasi variabel komunikasi pemasaran memiliki nilai signifikansi 0,020. Nilai signifikansi tersebut kecil dari $\alpha=0,05$ yang menunjukkan bahwa variabel komunikasi pemasaran berpengaruh signifikan terhadap loyaliats nasabah. Dengan demikian dapat disimpulkan bahwa ada pengaruh yang signifikan variabel komunikasi pemasaran terhadap loyalitas nasabah pada Bank Nagari Cabang Utama Padang.

\section{Pengaruh Kerelasian Nasabah terhadap Loyalitas Nasabah}

Berdasarkan pada tabel Uji-t yang telah disajikan untuk hipotesis kedua didapatkan hasil estimasi variabel kerelasian nasabah memiliki nilai signifikansi 0,023. Nilai signifikansi tersebut kecil dari $\alpha=0,05$ yang menunjukkan bahwa variabel kerelasian nasabah berpengaruh positif dan signifikan terhadap loyalitas nasabah. Dengan demikian dapat disimpulkan bahwa ada pengaruh kerelasian nasabah terhadap loyalitas nasabah pada Bank Nagari Cabang Utama Padang.

\section{KESIMPULAN}

Bedasarkan hasil penelitian dan pembahasan maka dapat disampaikan beberapa kesimpulan penelitian sebagai berikut:

1. Komunikasi pemasaran berpengaruh positif dan signifikan terhadap loyalitas nasabah. Kerelasian nasabah memiliki nilai signifikansi sebesar 0,020 , nilai signifikan tersebut lebih kecil dari alpha 0,05 .

2. Kerelasian Nasabah berpengaruh positif dan signifikan terhadap loyalitas nasabah. Kerelasian nasabah memiliki nilai signifikansi sebesar 0,023 , nilai signifikan tersebut lebih kecil dari alpha 0,05 .

\section{UCAPAN TERIMAKASIH}

Peneliti mengucapkan terima kasih kepada pihak-pihak yang telah memberikan dukungan dan dorongan dalam melakukan penelitian ini. Penghargaan dan ucapan terima kasih kepada Pihak Bank Nagari Cabang Utama Padang yang telah menyediakan akses kedalam. Sehingga memudahkan peneliti untuk mengumpulkan data sesuai dengan data yang peneliti butuhkan. Penghargaan dan terima kasih juga penulis ucapkan kepada Sekolah Tinggi Ilmu Ekonomi "Keuangan Perbankan dan Pembangunan", terutama Program Studi Manajemen yang telah memberikan support, mengizinkan dan memberikan tugas kepada penulis untuk melakukan penelitian dan penulisan jurnal ini.

\section{DAFTAR PUSTAKA}

Marlius, D. Putriani, I. (2019). Kepuasan Nasabah PT. Bank Rakyat Indonesia Unit Tapan Cabang Painan Dilihat dari Kualitas Layanan Customer Service. Jurnal Pundi. Volume 3. No. 2. Hal.111-122. https://doi.org/10.31575/jp.v3i2.151

Marlius, D. Ananda, F. (2019). Pengaruh Kualitas Pelayanan Website Akademik Terhadap Minat Kuliah di AKBP Padang. Jurnal Pundi, Vol. 03, No. 03. Hal. 191-204. https://doi.org/10.31575/jp.v3i3.190 
Marlius, D. (2018). Loyalitas Nasabah Bank Nagari Syariah Cabang Bukittinggi Dilihat Dari Kualitas Pelayanan. Jurnal Pundi. Volume 1. No. 3. Hal.12-22. https://doi.org/10.31575/jp.v1i3.60

Marlius, D. (2018). Pengaruh Dimensi Kualitas Pelayanan Website Akademik Terhadap Kepuasan Mahasiswa Pada STIE “KBP”. Jurnal Ipteks Terapan. Volume 12. No. 2. Hal. 116-128. http://doi.org/10.22216/jit.2018.v12i2.633

Marlius, D. RD Putra. (2018). Strategi Pengembangan Sulam Bayang. Jurnal Benefita: Ekonomi Pembangunan Manajemen Bisnis Dan Akuntansi. Volume 3. No. 2. Hal. 204-218. http://doi.org/10.22216/jbe.v3i2.3494

Marlius, D. (2017). Keputusan Pembelian Berdasarkan Faktor Psikologis Dan Bauran Pemasaran Pada PT. Intercom Mobilindo Padang. Jurnal Pundi. Volume 1. No. 1. Hal. 57-66. https://doi.org/10.31575/jp.v1i1.9

Mayliza, R. (2019). Pengaruh Kesadaran Merek, Asosiasi Merek Dan Perception Of Quality Terhadap Keputusan Pembelian Hospital Bed Merek Paramout Di PT. Aga Medika Utama Padang (Studi Kasus Rumah Sakit Umum Kota Padang). https://doi.org/10.17605/OSF.IO/VYQ4E

Marlius, D. (2016). Pengaruh Bauran Pemasaran Jasa Terhadap Minat Nasabah Dalam Menabung Pada Bank Nagari Cabang Muaralabuh. https://doi.org/10.31227/osf.io/vdqgx

Mayliza, R. (2019). Analisis Customer Satisfaction Dan Behavioral Intention Dilihat Dari Service Quality, Food Quality Dan Price/Value Di Restoran Mc Donald's Depok. https://doi.org/10.31219/osf.io/e2jrt

Putra, Y. E., \& Aziz, N. (2019). Pengaruh Kualitas Pelayanan Dan Kepuasan Pelanggan Terhadap Loyalitas Nasabah PT. Bank Rakyat Indonesia Cabang Padang. https://doi.org/10.31219/osf.io/hcsw2

Fernos, J., \& Putra, Y. E. (2019). Analisa Pengaruh Kualitas Pelayanan Terhadap Kepuasan Nasabah Pada PT. Bank Mega Syari'ah Padang. https://doi.org/10.31219/osf.io/y2baf

Fernandes, Y. D., \& Marlius, D. (2018). Peranan Customer Service Dalam Meningkatkan Pelayanan Kepada Nasabah Pada PT. Bank Pembangunan Daerah Sumatera Barat Cabang Utama Padang. https://doi.org/10.31227/osf.io/wrh3p

Hidayati, R. R., \& Marlius, D. (2018). Aktivitas Promosi Dalam Meningkatkan Dana Pihak Ketiga Pada PT. Bank Perkreditan Rakyat (BPR) Batang Kapas Pesisir Selatan. https://doi.org/10.31227/osf.io/8dgqn

Susanti, F. (2015). Pengaruh Bauran Promosi Terhadap Keputusan Klien Dalam Memilih Radio Carano Sebagai Media Promosi Iklan. https://doi.org/10.31227/osf.io/b9ws7 
Widayati, R. (2019). Aktivitas Pemasaran Produk Simpanan PT. Bank Tabungan Negara (Persero)Tbk Kantor Cabang Padang. https://doi.org/10.17605/OSF.IO/3Z5YC

Widayati, R. (2019). Penerapan Sistem Pembagian Pendapatan Pada Bank Mudharabah Nagari Syariah Cabang Padang. https://doi.org/10.17605/OSF.IO/BC3R5

Widayati, R. (2019). Aktivitas Pemasaran Produk Tabungan Pada PT. Bpr Rangkiang Denai Payakumbuh Barat. https://doi.org/10.17605/OSF.IO/S3UZM 